Peter Kiriri ${ }^{1}$

United States International University - Africa

(USIU-A)

Chandaria School of Business, Kenya
ORIGINAL SCIENTIFIC ARTICLE doi:10.5937/ekonomika1901011K Received November, 30, 2018 Accepted: February, 05, 2019

\title{
CHALLENGES FACING AFRICAN BUSINESS EXCELLENCE MODELS: A CASE STUDY OF COMPANY OF THE YEAR AWARDS (COYA)
}

\begin{abstract}
Business Excellence Models (BEM) are frameworks developed to guide organizations into best practices that lead to sustained high performance. These models are internationally recognized as both providing a framework to assist the adoption of business excellence principles, and an effective way of measuring how thoroughly this adoption has been incorporated. There are several BEMs adopted by different countries. North America, Europe, Asia, South America and Australia have over the years implemented National BEMs. However, in Africa, various countries have established National and industry/sector based BEMs with minimal success. This is an exploratory study focusing on reviewing existing literature on the BEMs and identifying challenges that the African BEMs have faced. The paper also provides some practical recommendations that can be adopted to ensure success of the BEMs.
\end{abstract}

Key words: business excellence models; national quality awards; Africa

JEL classification: M10, M11

\section{ИЗАЗОВИ МОДЕЛА ПОСЛОВНЕ ИЗВРСНОСТИ У АФРИЦИ: СТУДИЈА СЛУЧАЈА ПРЕДРЕДУЗЕһА ГОДИНЕ (СОУА)}

\begin{abstract}
Апстракт
Модели пословне изврсности (BEM) представљају оквире развијене да усмеравају организације ка најбољим праксама које воде до одрживих високих перформанси. Ови модели су међународно признати као оквир за помоћ при усвајању принципа пословне изврсности и као делотворан начин мерења колико су ови принципи примењени у организацији. Постоји неколико модела пословне изврсности који се користе у различитим земљама. Северна Америка, Европа, Азија, Јужна Америка и Аустралија имају националне моделе пословне изврсности. У Африци различите земље су креирале националне и индустријске/секторске моделе пословне изврсности. Међутим, примена ових модела није дала добре резултате. Ово истраживање се фокусира на преглед литературе о моделима пословне изврсности и идентификовање изазова са којима се суочавају модели пословне изврсности у Африци. Такође,
\end{abstract}

${ }^{1}$ pnkiriri@usiu.ac.ke 
рад даје практичне препоруке које треба усвојити ради успешне примене модела пословне изврсности.

Кључне речи: модели пословне изврсности; нациналне награде за квалитет; Африка

\section{Introduction}

Business Excellence Models (BEM) are frameworks developed to guide organizations into best practices that lead to sustained high performance. Business excellence is a continuous improvement to error-free performance by everyone in an organization so as to be the best in delivering high quality services which meet or exceed the expectation of customers. Business excellence has been adopted by organizations globally as a tool to enhance their competitiveness, locally and internationally. It ensures a firm's economic survival as the principles underlying the global business excellence framework builds a pathway to long term success and continuous improvement. Business excellence is also seen as an effective strategy to promote global quality awareness that countries have their own award system to recognize and reward organizations that demonstrate the highest standard of business excellence.

Excellence models can be traced back in Japan with the Deming Prize, which was established in 1952, to recognize the work of successful organizations in the Japanese manufacturing sector (Ghobadian \& Woo, 1994). It was the success of the Japanese companies in quality excellence and continuous improvements in the 1980s that drove Western countries to develop similar quality excellence models in these countries. The first quality award that was introduced to reward organizations that demonstrates significant growth in performance is the Deming Prize. The Deming Prize was established by the Board of Directors of the Japanese Union of Scientists and Engineers (JUSE) in 1951. The improved performance in Japanese companies under the influence of quality gurus such as, Deming and Juran inspired the United States to develop the Malcolm Baldrige Award.

The Malcolm Baldrige was designed to recognize American firms that practice effective quality management and make significant improvements in the quality of their goods and services. After the American Model came the European Quality Award (EQA) which was officially introduced by the European Foundation for Quality Management (EFQM). The Australian Quality Award was first established by Australian Quality Council (AQC) in 1988 and was later acquired by SAI Global (formerly known as Standards Australia International Limited) in February 2002. Over the years, other countries have established their excellence models with mixed results. These include Singapore, Malaysia, India, China, Brazil, Mexico, UAE, Saudi Arabia, among others. The major Business Excellence Models have driven the institution of quality distinctions around the world and served as benchmarks for national quality awards (Alonso-Almeida \& Fuentes-Frías, 2010). 
Table 1: Global Excellence Model Members

\begin{tabular}{|c|c|c|c|}
\hline Country & Organization & Award & $\begin{array}{l}\text { Administered / } \\
\text { Sponsor }\end{array}$ \\
\hline USA & $\begin{array}{l}\text { Baldrige Performance Excellence } \\
\text { Program }\end{array}$ & $\begin{array}{l}\text { Malcolm Baldrige National } \\
\text { Quality Award }\end{array}$ & $\begin{array}{l}\text { Government } \\
\text { Agency }\end{array}$ \\
\hline Japan & Japan Quality Award Council & Japan Quality Award & Industry \\
\hline Europe & $\begin{array}{l}\text { European Foundation for Quality } \\
\text { Management (EFQM) }\end{array}$ & $\begin{array}{l}\text { European Foundation for Quality } \\
\text { Management Model. }\end{array}$ & Industry \\
\hline Australia & $\begin{array}{l}\text { Australian Organizational Excellence } \\
\text { Foundation (AOEF) }\end{array}$ & $\begin{array}{l}\text { Australian Organizational } \\
\text { Excellence Awards }\end{array}$ & Industry \\
\hline Singapore & $\begin{array}{l}\text { Enterprise Singapore formerly } \\
\text { (SPRING Singapore) }\end{array}$ & Singapore Quality Award & Government \\
\hline Malaysia & Malaysia Productivity Corporation & $\begin{array}{l}\text { Malaysia Business Excellence } \\
\text { Framework }\end{array}$ & $\begin{array}{l}\text { Government of } \\
\text { Malaysia }\end{array}$ \\
\hline India & $\begin{array}{l}\text { The Confederation of Indian Industry } \\
\text { (CII) }\end{array}$ & $\begin{array}{l}\text { CII-EXIM Bank Award for } \\
\text { Business Excellence }\end{array}$ & Industry \\
\hline China & China Association for Quality (CAQ) & China Quality Award & Industry \\
\hline Brazil & $\begin{array}{l}\text { Fundação Nacional da Qualidade } \\
\text { (FNQ) - National Quality Foundation }\end{array}$ & $\begin{array}{l}\text { El Prêmio Nacional da } \\
\text { Qualidade }{ }^{\circledast} \text { (PNQ) - The National } \\
\text { Quality Award }\end{array}$ & Industry \\
\hline $\begin{array}{l}\text { Iberian } \\
\text { Peninsula } \\
\text { and Latin } \\
\text { America }\end{array}$ & $\begin{array}{l}\text { Fundación Iberoamericana para la } \\
\text { Gestión de la Calidad (FUNDIBEQ) }\end{array}$ & Ibero-American Quality Award & $\begin{array}{l}\text { Industry and } \\
\text { Government }\end{array}$ \\
\hline Mexico & $\begin{array}{l}\text { Instituto para el Fomento a la Calidad } \\
\text { Total (IFCT) - Mexican Institute for } \\
\text { Competitiveness }\end{array}$ & Mexican Quality Award & Industry \\
\hline
\end{tabular}

The main National BEMs have formed the Global Excellence Model (GEM) Council. GEM consists of organizations that are recognized globally as the guardians of premier Excellence Models and Award processes in their specific geographical region/area or trading block. Currently, there are 10 members of the GEM Council. South Africa used to be a member of the GEM council but was suspended due to lack of meeting membership criteria. At the moment, there is no African country or region represented in the GEM Council.

\section{Benefits of BEMs}

There are different reasons as to why organizations participate or implement the BEMs. These can be categorized as both internal and external reasons. On the other hand, according to Gómez-López, Serrano-Bedia, and López-Fernández, the motivations can be grouped into: external market reasons, external reasons of requirements and internal institutional reasons (Gómez-López, Serrano-Bedia, \& López-Fernández, 2015). Heras-Saizarbitoria, Casadesus, and Marimon (2011) found that the critical drivers for implementing the EFQM model were of an internal character which included: productivity issues, optimization of resources, improvement of the quality of products and services, and reduction of costs. 
Boulter, Bendell and Dahlgaard posited that organizations that had been awarded for quality performed better than those that had no awards or recognition for excellence (Boulter, Bendell \& Dahlgaard, 2013). Additionally, it was also observed that there was significant improvement by participating in the years following the award (Corredor \& Goni, 2010). This is due to the fact that on the first year of participation, most businesses may be at the stage of developing their quality systems and processes. The awarding process is able to identify various gaps which is worked on in the consecutive years.

It has also been found that by participating in the BEM, organization's image is improved, there is greater client satisfaction as well as increased commitment of employees (Tutuncu \& Kucukusta, 2007). In some instances, when the model is implemented within the organization and there is improvement of the way things are done, this leads to improved employees level of satisfaction (Nabitz, Jansen, van der Voet \& van den Brink, 2009; Tutuncu \& Kucukusta, 2010; Krstić \& Krstić, 2015). Participation has also been linked to the greater competitiveness of the business and to obtaining competitive advantages by participating organizations (Pesic \& Dahlgaard, 2013; Santos-Vijande \& Alvarez-Gonzalez, 2007).

BEMs have also been found to drive improved organization performance as a result of increased profits (Dadfar, Dahlgaard, Afazeli \& Brege, 2015). Due to the role that productivity and innovation plays in the BEM process, participating companies have been found to have a greater predisposition to innovation (BayoMoriones, MerinoDíaz-de-Cerio, Escamilla-de-León \& Selvam, 2011; Gutiérrez, Torres, \& Molina, 2010), strengthening the effectiveness of knowledge management projects and optimization of the use of the information systems.

\section{Barriers in Implementation of BEMs}

Despite the identified benefits and impacts of BEMs, various barriers have been found affecting their implementation. Santos-Vijande and Alvarez-Gonzalez found that the main barriers were the lack of understanding of the model by organizations and the lack of a clear quality leadership (Santos-Vijande \& Alvarez-Gonzalez, 2007). Due to the complexity of the models, it was a challenge to understand the same especially for smaller and first entrant organizations. Heras-Saizarbitoria et al. found that for most organizations, lack of resources presented the single most critical obstacle followed by model complexity which affected effective adoption of the model (Heras-Saizarbitoria et al., 2011).

The models have resource demanding activities and detailed model criteria for participating companies (Eriksson, 2003; Eriksson \& Garvare, 2005) making it difficult for will companies to participate. The resources required in the implementation of the model were sometimes a barrier especially for resource deficient organizations both large and small. The resources required other than financial resources were the human resources for undertaking the self-assessment and managing the entire process of the external assessors' visits as conducting the self-assessment is a time-consuming task (Rusjan 2005). This was similarly found out by Gómez-López, López-Fernández and Serrano-Bedia (2015) who indicated that the lack of time, physical and financial resources were barriers affecting EFQM. 
Other barriers were organizational cultural barriers and behavioral barriers. These were factors derived for an organization being and attitude towards quality and quality improvement processes. Inherent in this is the issue of leadership and teamwork. For successful participation in the model, the role of each organizational member is critical since quality in an organizational wide undertaking. Resistance to change or organizational initiatives also affects implementation (Dahlgaard \& Dahlgaard, 2013). Lack of commitment form top management was also identified as a key barrier. Top commitment must provide exceptional support to the process both in corporate resources and personal involvement (Porter \& Tanner, 2004). Dahlgaard \& Dahlgaard (2013) stated that the excellence frameworks can create bureaucracy due to the need for a massive amount of paperwork and documented procedures (Dahlgaard \& Dahlgaard, 2013).

Excellence models and quality awards have also been criticized as having inherent weaknesses. Loomba and Johannessen criticize the MBNQA and concluded that the model had some levels of unfairness and that superficially and publicity related problems, may arise in the process of applying (Loomba \& Johannessen, 1997). The unfairness of the program was the prohibitive cost of joining the competition, the imbalance in the number of laureates between competing categories and the conflict of interest arising when examiners judging the competition also work as consultants for competing companies. The superficial area included that the Baldrige program was used by the recipients only to get free and extensive publicity and that companies with mediocre consumer ratings won and thus got undeserved positive media coverage. Rajan (2005) stated that due to the lack of clear understanding of the value of achieving business excellence, some companies focus on improving the score itself and the getting of the award rather than working to achieve the long term advantages of business excellence.

\section{Africa BEMs}

In Africa, several quality awards and excellence models have been initiated over the years as indicated in the table below. The success of the African models is mixed as most of them are either dormant or facing operational challenges. Nigeria with the support of UNIDO is the latest to develop a quality model in 2017. Other than Kenya and Nigeria, the other counties did not have the award process conducted in 2017. Due to the fact that the models are run on a not for profit basis, sustainability of these models have been a challenge.

Table 2: African Quality Models

\begin{tabular}{|l|c|l|l|}
\hline Country & Region & Name of Award & $\begin{array}{l}\text { Year } \\
\text { Established }\end{array}$ \\
\hline Mauritius & Eastern Africa & Mauritian National Quality Award & 1992 \\
\hline Egypt & Northern Africa & The National Award for Excellence in Quality & 1997 \\
\hline South Africa & Southern Africa & South African Excellence Award & 1997 \\
\hline Kenya & Eastern Africa & Company of the Year Awards & 1999 \\
\hline Nigeria & West Africa & Nigeria National Quality Awards & 2017 \\
\hline
\end{tabular}


As mentioned, part of the challenges facing the African Models is sustainability. Most of them have been having challenges in being able to administer the annual assessment process and identify the company to award for quality. As indicated in the table below, apart from Kenya and Nigeria, the other known models have not had the award process since 2014 .

Table 3: African Quality Models Performance

\begin{tabular}{|l|l|c|l|}
\hline Country & Sponsors & $\begin{array}{c}\text { Year } \\
\text { Established }\end{array}$ & In existence \\
\hline Mauritius & Government & 1992 & Last Awards in 2013 \\
\hline Egypt & Government & 1997 & Last Awards in 2014 \\
\hline South Africa & Non-Governmental Institutions & 1997 & Last Awards in 2004 \\
\hline Kenya & Non-Governmental Institutions & 1999 & Last Awards in 2017 \\
\hline Nigeria & Government & 2017 & Last Awards in 2017 \\
\hline
\end{tabular}

\section{Study Focus Questions}

Due to the challenges facing the African BEMs, the current exploratory study attempted to address the following two research questions:

1. What have been the challenges facing the success of the African BEMs?

2. What strategies can the African BEMs use to ensure sustainability of their frameworks?

\section{Methodology}

In order to address the research questions above, an exploratory study was undertaken. This study was to inform a further detailed study on the viability and sustainability of the BEMs. Data for this study was collected from information from the Kenya Institute of Management (KIM), the sponsors of the Kenyan BEM (Company of the Year Awards - COYA). Interviews were also conducted with the COYA Secretariat and past participating companies. Further, information was gathered from experts who were involved in the award process. The information was analyzed using basic exploratory techniques. The collected information will assist in developing quantitative tools for gathering information from past and present participants, assessors, as well as companies that have never participated.

\section{Challenges Facing African BEMs}

\section{Process Based Challenges}

The process of participating in COYA was identified as a barrier to continued participation. This was because the process was seen to be time consuming. Most of the participants felt that the process required a dedicated project team to go through the 
champions training, self-assessment and on-site assessor engagements. On average it was felt that the process required the dedicated team to spend at least 3 months on the process, yet the same team had to fulfil their job requirements as per their job descriptions. For most organizations, this was a tall order and thus after participating once in the process some declined to further engage. It was also noted that a number of organizations were recruited, paid the participation fees but due to the demands of the process declined midway to proceed to finalization of the process.

Coupled with the time demands of the process is the efforts required. Due to the nature of the assessment tool, any scoring was required to be supported with evidences. Such required gathering of volumes of evidences from different departments, sections, branches and units. This required internal buy-in and support from those to provide evidence which was not assured in some organizations thus making the process difficult. At the end of it, the participants provided both relevant and irrelevant evidences to the assessors making it a challenge in evaluating the submitted evidence for the award and in turn make it difficult for objective scoring of the organization.

The lengthy process of preparing to participate and undertaking the assessment was also indicated as a barrier to participation. The COYA process required that after recruitment of a company to participate, it was a requirement that the company identifies between $3-5$ employees as champions to drive the process internally. Those identified were to undergo a 3 day intensive Champions Training that would equip them with the capacities to sell and drive the process within the company. While this was a noble idea, some organizations were hard pressed to send staff away on 3 days training. Even those that did, it was a challenge to rally the whole organization and especially top management to support the process. This again took time to sell the model and get everyone involved.

The champions also faced challenges in getting cooperation from the different departments and sections who were required to be involved in the assessment. On the other hand, some of the companies indicated that participating in the process for a second time led to fatigue of the champions thus affecting the quality of the assessment and the evidence submitted. This is collaborated by the COYA Secretariat who indicated that same evidence was submitted year in year out by those who participated for several years. This would end with the conclusion that there were no new quality improvement initiatives undertaken even after a preceding year of assessment.

\section{Tool Based Challenges}

In terms of the tool, most of the respondents opined that the tool was too complex to fill. During the self-assessment, some of the respondents indicated that they did not understand the tool fully and thus filled some sections just for the purpose of filling. Whereas champions were taken through a 3-day process of understanding the tool and the COYA process, it was evident that the tool due to its complexity was not well understood especially the scoring part. This led participants to score themselves highly even in areas where there was no evidence to support such a high scoring. In a few instances, the self-assessment and filing of the tool was done by members of staff who had not even attended the champions training and this lacked familiarity and understanding of what was required. There was also the complaint of too many questions making the tool too long and demanding. 
The complexity of the questions was also an issue. While the questions would have made sense to employees in some specific levels and functions, in some instances the self-assessment was let to employees who did not have the ability and competence to fill it. The tool and some questions were deemed too complex by some participants. Others described the tool as being too abstract and circumstantial and difficult to use especially for organizations that were participating for the first time. Due to the fact that the COYA heavily borrowed from EFQM and Baldridge in its design, some of the issues therein might not have been relevant for a developing country and thus the complexity.

Other participants felt that the language and terminologies used were hard to understand and appropriate for a large multinational organization. Though the tool had instructions on how to fill, they felt some sections did not have detailed and comprehensive instructions to aid step by step successful self-assessment.

Some respondents also indicated that the tool had similar questions repeated in different sections of the tool and hence felt it was duplicative. Due to this, when there were different employees of an organization filling a particular section, there was a high likelihood of differing responses from same organization. To avoid the duplication, the filling of the tool required a controlled centralized process through a project team approach. This require several engagements before sending the self-assessment to review the responses, which according to some respondents took several days.

Most of the respondents felt the tool was also too academic and theoretical and as having been developed by consultants who did not have a sound understanding of the issues in organizations. This, they alluded as a result of the feeling that some of the questions asked in the tool were not relevant to them and their sector. COYA used a standard tool to evaluate all organizations regardless of sector, industry or orientation.

\section{Perceived Benefits Challenges}

The perceived benefits of participating in the COYA process varied among the different entrants/participants. A number of them participated for the sole purpose of winning an award as opposed to business excellence and quality improvements. Whereas the objective of the model is to help organizations improve on their processes and results, when the reason behind participating was to win an award/trophy, some companies ended up employing consultants to prepare them to win. When such was undertaken, the objective of quality improvement was lost. The win in the end meant nothing to the organization in terms of quality improvement as quality improvement and excellence was not attained. As such seeking an Award for outstanding performance against the criteria can be a major distraction from the main game of building excellence capability.

Some of the respondents did not perceive much benefits from the assessment report submitted at the end of the process as well as the benchmarking visits organized by the Secretariat. In terms of the report, some participants complained that the report either arrived too late or wasn't forthcoming. The quality of the report was put into question especially on the issues and recommendations. Some participants stated that the report received did not reflect their companies and in some instances the gaps identified in the report were nonexistent in the organization. The recommendations were also found to be either irrelevant or inappropriate for the organization. In some instances, the report was a cut and paste from a previous report or that of another organization. 
While benchmarking with the winners was one of the driving force and benefit to participating in the COYA process, it was felt that the same did not adequately achieve the intended outcomes. In terms of benchmarking, some of the participants identified time as the main hindrance as well as objectives of the same. They felt that the benchmarking was a visit with minimal lessons learnt as it was not structured as a learning event. This was because the participants wanted to have a detailed understanding of what made the organization win in the category and what they non winners would do to improve quality. Some felt the benchmarking visits failed as most of the time was spent in a conference room as opposed to visiting the departments and seeing what the organization did in detail. Others attributed the shortcoming to benchmarking to the numbers of participants involved in the exercise which made it ineffective.

\section{Cost Based Challenges}

Due to the complexity of the process, inherently the cost of the process was also quite high. According to the COYA Secretariat, participation fee was $\$ 7,000$ per company. This cost covered the training of champions and assessor visits to the companies. It excluded participation in the quality awards conferment dinner ball. Some companies felt that this was quite prohibitive and thus limited their participation. Some of those who had participated felt that the process did not quite deliver value for money. The Secretariat indicated their frustrations at convincing companies to pay the amount and when they did, most companies paid a commitment fee with the balance being an odious task to collect.

\section{Leadership and Organizational Culture Based Challenges}

For any quality excellence to succeed organizational leadership is critical. Some of the respondents indicated lack of leadership support in their organizations to the process. Some of the companies relegated the process to middle level management with little executive support. This was deemed to frustrate the champions especially when data and evidence was required from some sections within the organization.

Some respondents indicated the unwillingness of some managers to release their champion trained staff to the assessment process. The lacked of a shared quality vision from management affected the success of the initiative. This lack of ownership made the initiative to appear as owned by the champions as opposed to an organization wide quality improvement initiative. As a result, the champions owned the process and worked exclusively on their own. Even when a company won, the win was attributed to the champions and lacked corporate wide ownership and celebration of results.

On the other hand, where improvements were recommended, the same were not implemented since in some organizations the buy in was minimal. This was collaborated from the Secretariat who stated that some companies never bothered to review the recommendations of assessors as contained in the assessment report. This was visible during the consequent periods of assessment.

The dominant organizational culture was also a barrier. Where an organization lacked a quality philosophy, innovative culture, team based culture and a change readiness mindset, acceptance of the model and quality improvements was a challenge. 


\section{Credibility of the Excellence Model Process}

The credibility of the process came out as an issue to participating. Where some organizations felt they were not treated fairly, others felt that the whole awarding of business excellence was quite subjective with some participants indicating that they felt that the winners were predetermined. The credibility of the assessors was also identified as a barrier to participating. Some respondents questioned the professionalism of the assessors on different aspects. Some felt that some of the assessors were not competent enough to undertake the company organization. Others were of the view that some assessors were more driven by person interests especially in securing for a consultancy opportunity and thus would indicate gaps within the organization in order to position themselves for the same. It was also pointed that the some of the assessors had a consulting relationship with the winning organization and thus a feeling of unequal playing round.

\section{Recommendations}

In order to improve the performance of the African BEMs, and based on the challenges articulated from the different respondents, a number of recommendations are given:

The sponsors of a BEM should engage in aggressive marketing of the framework focusing more on the perceived benefits of participating. Case studies showing the before and the after of past successful participants should be developed and communicated to would be participants. The same should stress the tangible benefits of participant in the framework. There is a need to relook at the benchmarking visits and structure the same as a strategic outcome of the process.

Need to simplify the process. The sponsors of the model should consider simplifying the process and making it more relevant to the participating organizations. As it was found that some companies shied off to participate or complete the process due to this complexity. The tool should also be shortened with fewer questions as opposed to the current tool which has over 140 questions, each of which requires supportive evidence. The tool should be simple to understand and as simple as possible to implement. Such a tool should also show and specify how all the essentials of business excellence can be linked.

In linking the essentials of business excellence, the sponsors should consider developing an automated and integrated assessment tool. This will make it easier for objective self-assessment and ease of sharing the assessment organization-wide as well as simultaneously working on key parameters of the tool from different locations of an organization. It would ensure that inbuilt automated controls are embedded in the tool ensuring that an awarded score will only be accepted upon providing relevant evidence.

The involvement of stakeholders in tool development and validation would ensure support of the same. BEM sponsors should consider a participatory process of tool development and review and inputs from stakeholders about the process. This would ensure buy-in from companies. The companies should also be given a period to trial the tool and process before participating in the award process.

The organizers of BEMs should consider reducing the participating fees for the companies. With a redefined tool and process, the costs of administering the same should be lower leading to reduced participation fees. They should also look for partnerships 
with other business associations to share in the costs of the process. Partnerships should be sought from government and other stakeholders to support the process with resources. Such partnerships should be long-term in nature to ensure sustainability. Companies should be encouraged to set aside a resource budget for the implementation of the model.

Some of the successful National Quality Awards have the sponsorship of the countries governments including being owned and driven by a government agency. The sponsors should consider the involvement of the government $n$ the process and in order to make it a National Award to create a separate entity with the government, chamber of commerce, association of manufacturers, private sector alliance as well as other professional and membership bodies to develop a National Framework. Currently, there are many fragmented sector based award frameworks, some of which may not be driven by the need for quality and business excellence.

There should be a thorough selection and recruitment processes for the assessors to ensure that only professionally competent assessors who have no conflict of interest are chosen. A model of assessor development should be instituted that would see assessors starting off at an entry level and through capacity building are developed to the intermediate level and finally to an advanced competency level. The institutional should also developed long term mutually beneficial relationships with assessors for the credibility and sustainability of the BEM model.

\section{References}

Alonso-Almeida, M. M., \& Fuentes-Frías, V. G. (2012). International quality awards and excellence quality models around the world. A multidimensional analysis. Quality \& Quantity, 46(2), 599-626.

Boulter, L., Bendell, T., \& Dahlgaard, J. (2013). Total quality beyond North America: A comparative analysis of the performance of European Excellence Award winners. International Journal of Operations \& Production Management, 33(2), 197-215.

Bayo-Moriones, A., Merino-Díaz-de-Cerio, J., Escamilla-de-León, S. A., \& Selvam, R. M. (2011). The impact of ISO 9000 and EFQM on the use of flexible work practices. International Journal of Production Economics, 130(1), 33-42.

Corredor, P., \& Gon i, S. (2010). Quality awards and performance: Is there a relationship? The TQM Journal, 22(5), 529-538.

Dadfar, H., Dahlgaard, J. J., Afazeli, S., \& Brege, S. (2015). Quality, export and domestic market performance: The case of pharmaceutical firms in Iran. Total Quality Management \& Business Excellence, 26(9-10), 938-957.

Dahlgaard-Park,S. M. \& Dahlgaard,J. J.(2007). Excellence-25 years'evolution. Journal of Management History, 13(4), 371-393.

Eriksson, H., Gremyr, I., Bergqvist, B. et al. (2016). Exploring Quality Challenges and the Validity of Excellence Models. International Journal of Operations \& Production Management 
Eriksson, H. (2003a). Organizational value of participating in a quality award process. A Swedish study. The TQM Magazine, 16 (2), 78-92.

Eriksson, H. (2003b). Experiences of working with in-company quality awards - A case study. The TQM Magazine, 15 (2), 397-407.

Eriksson, H. \& Garvare, R. (2005). Organizational performance improvement through quality award process participation. International Journal of Quality and Reliability Management, 22 (9), 894-912.

Eriksson, H. \& Hansson, J. (2003). The impact of TQM on financial performance. Measuring Business Excellence, 7(1), 36-50.

Gutiérrez, L. J. G., Torres, I. T., \& Molina, V. B. (2010). Quality management initiatives in Europe: An empirical analysis according to their structural elements. Total Quality Management, 21(6), 577-601.

Ghobadian, A. \& Woo, H.S. (1994). Characteristics, benefits and shortcomings of four major quality awards. International Journal of Quality and Reliability Management, 13 (2), 10-44.

Gómez-López, R., Serrano-Bedia, A. M., \& López-Fernández, M. C. (2015). Motivations for implementing TQM through the EFQM model in Spain: An empirical investigation. Total Quality Management \& Business Excellence, 27(11-12), 1-22

Heras-Saizarbitoria, I., Casadesus, M., \& Marimon, F. (2011). The impact of ISO 9001 standard and the EFQM model: The view of the assessors. Total Quality Management, 22(2), 197-218.

Heras-Saizarbitoria, I., Marimon, F., \& Casadesús, M. (2012). An empirical study of the relationships within the categories of the EFQM model. Total Quality Management \& Business Excellence, 23(5-6), 523-540.

Loomba, A.P.S \& Johannessen, T. B. (1997). Malcolm Baldrige National Quality Award. Critical issues and inherent values. Benchmarking for Quality Management \& Technology, 4(1), 59-77.

Krstić, B., Krrstić, M. (2015). Model of irrational behavior of household and firm. Ekonomika, 61(4), 1-10.

Nabitz, U., Jansen, P., van der Voet, S., \& van den Brink, W. (2009). Psychosocial work conditions and work stress in an innovating addiction treatment centre. Consequences for the EFQM Excellence Model. Total Quality Management, 20(3), 267-281.

Pesic, M. A., \& Dahlgaard, J. J. (2013). Using the Balanced Scorecard and the European Foundation for Quality Management Excellence model as a combined roadmap for diagnosing and attaining excellence. Total Quality Management \& Business Excellence, 24(5-6), 652-663.

Tutuncu, O., \& Kucukusta, D. (2007). Relationship between organizational commitment and EFQM business excellence model: A study on Turkish quality award winners. Total Quality Management, 18(10), 1083-1096. 
Tutuncu, O., \& Kucukusta, D. (2010). Canonical correlation between job satisfaction and EFQM business excellence model. Quality \& Quantity, 44(6), 1227-1238.

Santos-Vijande, M. L., \& Alvarez-Gonzalez, L. I. (2007). TQM, firm's performance: An EFQM excellence model research based survey. International Journal of Business Science and Applied Management, 2(2), 21-41.

Suárez, E., Calvo-Mora A., Roldán, J., \& Periá nez-Cristóbal, R. (2017). Quantitative research on the EFQM excellence model: A systematic literature review (19912015). European Research on Management and Business Economics, 23 (1), $147-156$ 